\title{
CAPITAL GAINS TAXES AND STOCK REACTIONS TO QUARTERLY EARNINGS ANNOUNCEMENTS
}

\author{
Jennifer L. Blouin \\ Jana Smith Raedy \\ Douglas A. Shackelford \\ Working Paper 7644 \\ http://www.nber.org/papers/w7644 \\ NATIONAL BUREAU OF ECONOMIC RESEARCH \\ 1050 Massachusetts Avenue \\ Cambridge, MA 02138 \\ April 2000
}

We appreciate the helpful comments from two anonymous referees, Jeff Abarbanell, Linda Bamber (editor), Mary Barth, Merle Erickson, Robert Lipe, Sylvia Madeo (associate editor), Ed Maydew, Kevin Raedy, and workshop participants at the 1999 Duke/North Carolina Accounting Research Fall Camp and the Duke/North Carolina public finance workshop. We also acknowledge the contribution of I/B/E/S International Inc. for providing earnings per share forecast data available through the Institutional Brokers Estimate System. These data have been provided as part of a broad academic program to encourage earnings expectations. The views expressed herein are those of the authors and do not necessarily reflect the position of the National Bureau of Economic Research.

(C) 2000 by Jennifer L. Blouin, Jana Smith Raedy, and Douglas A. Shackelford. All rights reserved. Short sections of text, not to exceed two paragraphs, may be quoted without explicit permission provided that full credit, including $\odot$ notice, is given to the source. 
Capital Gains Taxes and Stock Reactions to Quarterly Earnings Announcements Jennifer L. Blouin, Jana Smith Raedy, and Douglas A. Shackelford

NBER Working Paper No. 7644

April 2000

JEL No. H24, G12, G14

\begin{abstract}
This paper examines the impact of capital gains taxes on equity pricing. Examining three-day cumulative abnormal returns for quarterly earning announcements from 1983-1997, we present evidence consistent with shareholders' capital gains taxes affecting stock price responses. To our knowledge, this is the first study to link shareholder taxes and share price responses to earnings releases. The results imply that shares trade at higher (lower) prices when individual investors face incremental taxes (tax savings) created by selling appreciated (depreciated) shares before they qualify for long-term treatment. Unlike prior studies that have focused on price reactions in settings where shareholder taxes are unusually salient (e.g., tax law changes, turn-of-the-year trading, or taxsensitive transactions), this study finds the imprint of capital gains taxes in a more general setting.
\end{abstract}

Jennifer L. Blouin

Kenan-Flagler Business School

Campus Box 3490, McColl Building

University of North Carolina

Chapel Hill, NC 27599-3490

Douglas A. Shackelford

Kenan-Flagler Business School

Campus Box 3490, McColl Building

University of North Carolina

Chapel Hill, NC 27599-3490

and NBER

doug_shack@unc.edu
Jana Smith Raedy

Kenan-Flagler Business School

Campus Box 3490, McColl Building

University of North Carolina

Chapel Hill, NC 27599-3490 


\section{Capital Gains Taxes and Stock Reactions to Quarterly Earnings Announcements}

\section{INTRODUCTION}

No issue is more fundamental to accounting, finance, and economics than price formation. Many accounting studies investigate whether taxes are a determinant of prices. Settings include merger and acquisition premiums (e.g., Hayn 1989; Erickson 1998; Erickson and Wang 1999; Maydew, Schipper and Vincent 1999; Henning, Shaw and Stock 2000; Henning and Shaw 2000; Ayers, Lefanowicz and Robinson 2000), non-equity securities (e.g., Shackelford 1991; Guenther, 1994; Engel, Erickson and Maydew 1999), leases (e.g., Stickney, Weil and Wolfson, 1983), research and development (e.g., Berger 1993), and insurance (e.g., Ke, Petroni and Shackelford, 2000). A particularly active area in accounting is the impact of investor-level taxes (dividends and capital gains) on share prices (Dhaliwal and Trezevant 1993; Landsman and Shackelford 1995; Erickson 1998; Erickson and Maydew 1998; Blouin, Raedy, and Shackelford 1999; Guenther 1999; Guenther and Willenborg 1999; Harris and Kemsley 1999; Collins, Hand and Shackelford 2000; Collins and Kemsley 2000; Gentry, Kemsley and Mayer 2000; Harris, Hubbard, and Kemsley 2000; Lang and Shackelford 2000; among others).

This paper extends this literature to analyze the impact of shareholders' capital gains taxes on stock price responses to quarterly earnings announcements. This enables us to assess whether price movements associated with capital gains tax incentives exist in a generalized setting. Focusing on a public disclosure of primary interest to accountants, quarterly earnings announcements, we predict that the price-earnings relation varies with measures involving the spread between long-term and short-term capital gains tax rates, whether the news is good or bad, and the stock performance during the preceding holding period (currently one year). The 
wider the spread, the better the news, and the greater the past price appreciation, the more likely individual capital gains tax incentives apply upward price pressure around the earnings release.

The intuition behind these relations is straightforward. Suppose a public disclosure, such as an earnings announcement, induces investors to rebalance their portfolio. If sellers are individuals who have held the stock for less than one year, any gains will be taxed at the federal short-term capital gains tax rate (currently capped at 39.6 percent). If the individual investors had intended to hold the stock until it qualified for long-term capital gains tax rates (currently capped at 20 percent), then investors must trade-off the benefits of rebalancing with the tax costs of selling (i.e., taxes under short-term treatment versus taxes under long-term treatment).

Under such conditions, good (bad) news disclosures can constrict (expand) the supply of equity, creating upward (downward) price pressure (see Shackelford and Verrecchia 2000). Thus, for good news, it may be necessary for buyers to compensate sellers through higher prices for incremental taxes associated with short-term capital gains taxes. For bad news disclosures, sellers may accept less compensation to garner favorable short-term capital losses.

Unrealized gains and losses associated with past stock performance further complicate the sales decision. If the stock has appreciated during the long-term capital gains holding period, sellers can face incremental short-term capital gains taxes, whether the news is good or bad. Thus, sellers may demand compensation through higher prices for incremental taxes. Likewise, if the stock has depreciated, sellers may enjoy favorable short-term capital loss treatment, whether the news is good or bad. ${ }^{1}$ Therefore, sellers may accept lower prices to ensure favorable

\footnotetext{
${ }^{1}$ Another potential price determinant is the "lock-in" effect of the capital gains tax. Similar to the tax incentives to defer selling until shares qualify for long-term treatment, which this study investigates, the lock-in effect is the incentive to defer selling appreciated property, thus postponing taxation indefinitely. Unlike the individual shortterm/long-term tradeoffs that are the focus of this study, the lock-in effect applies to all taxable taxpayers, individual and other, and applies regardless of the holding period. The empirical tests in this study include an explanatory variable to control for any possible lock-in effects.
} 
short-term capital loss treatment.

The evidence in this paper is generally consistent with capital gains tax incentives affecting share prices. We regress three-day cumulative abnormal returns for 1983-1997 quarterly earnings announcements on unexpected earnings, the spread between short-term and long-term rates (ranging from zero to 30 percentage points), the change in the firm's price during the holding period (ranging from six to 18 months), interactions of these variables, and controls. The interactions are constructed to estimate the incremental capital gains taxes faced under shortterm treatment, rather than long-term treatment. Consistent with capital gains taxes affecting share prices, we find that cumulative abnormal returns are increasing in the incremental shortterm capital gains taxes.

To assess the robustness of our finding that capital gains tax incentives affect priceearnings relations in short windows, we conduct several additional tests. They include evaluating price responses to another public disclosure (joining the S\&P 500), trading volume around earnings releases, firms' ownership structure, and post-announcement abnormal returns. After considering all the evidence, we remain unable to reject the original finding that capital gains tax incentives affect share responses to quarterly earnings announcements.

To our knowledge, this is the first study to link shareholder taxes and share price responses to earnings announcements. It differs from most recent documentations of capital gains taxes affecting share prices because it tests whether capital gains taxes affect equity value in a generalized setting, rather than a setting where shareholder taxes might be unusually salient. To maximize power, prior studies typically focus on settings where capital gains tax effects should be unusually strong, including changes in the tax law (e.g., Amoako-Adu, Rashid, and Stebbins 1992; Guenther and Willenborg 1999; Blouin, Raedy, and Shackelford 1999; Guenther 
1999; Lang and Shackelford 2000; Sinai and Gyourko 2000), companies held mostly by individuals, such as initial public offerings, where individual tax incentives likely are more influential (e.g., Reese 1998; Guenther and Willenborg 1999; Blouin, Raedy, and Shackelford 1999), periods when tax planning likely is most prevalent, such as year-end, (e.g., Dhaliwal and Trezevant 1993; Poterba and Weisbenner 1998) and transactions where tax factors are known to be important, such as mergers and acquisitions (e.g., Hayn 1989; Landsman and Shackelford 1995; Erickson 1998; Erickson and Wang 1999; Henning, Shaw and Stock 2000). Rather than examine conditions that enhance the probability that capital gains taxes matter, this study intentionally evaluates an event, quarterly earnings announcements, that should not bias in favor of finding that taxes matter. ${ }^{2}$

The paper develops as follows. The next section reviews salient capital gains tax provisions. Section III develops testable hypotheses. Sections IV and V detail empirical tests. Closing remarks follow.

\section{CAPITAL GAINS TAXES}

All taxable shareholders recognize gain (loss) to the extent a stock sells for more (less) than the investor's tax basis. Individuals alone, however, face different tax rates depending on how long they have owned the property. ${ }^{3}$ Under current U.S. law, the maximum personal

\footnotetext{
${ }^{2}$ In this regard, this paper resembles Collins and Kemsley (2000) who report dividend tax and capital gains tax capitalization from an analysis of 68,283 observations from 1975-1997, using a modification of Ohlson's (1995) residual-income valuation model. However, unlike Collins and Kemsley, this paper relies on a capital markets event study approach to assess whether capital gains taxes affect stock prices.

${ }^{3}$ Before 1987, corporations also enjoyed favorable long-term capital gains taxation. For example, from 1979-1986, the maximum statutory corporate long-term capital gains tax rate was 28 percent while other corporate taxable income was taxed at a maximum statutory tax rate of 46 percent. Conclusions are insensitive to inclusion of pre1987 years in our analysis. Both individuals and corporations face limitations on the immediate deductibility of capital losses. Currently individuals are limited to an annual $\$ 3000$ deduction for capital losses in excess of capital gains. Corporations cannot deduct capital losses in excess of capital gains.
} 
statutory tax rate for gains on property held for more than a year ("long-term") is 20 percent while the maximum personal statutory tax rate for other gains ("short-term") is 39.6 percent.

Determining whether the favorable long-term tax rate applies to an individual's sale is a complex calculation. Shackelford (2000) shows that the distinction between long-term and short-term capital gains tax rates only matters if during the taxable year, an individual realizes (i) no more short-term capital losses than short-term capital gains and (ii) no more long-term capital losses than long-term capital gains. If both conditions hold, then postponing one dollar of gain until it qualifies as a long-term capital gain reduces total taxes by 19.6 cents (the short-term capital gains tax rate of 39.6 percent less the long-term capital gains tax rate of 20 percent), using current tax rates. Similarly, if both conditions hold, accelerating one dollar of loss so that it avoids long-term capital loss treatment reduces total taxes by 19.6 cents. If either condition does not hold (i.e., total short-term capital losses exceed total short-term capital gains or total longterm capital losses exceed total long-term capital gains), then the same marginal tax rate applies to a capital gain or loss, no matter whether it is long-term or short-term. ${ }^{4}$

Table 1 details the marginal tax rates under various assumptions from 1978 to 1998 . The tests throughout this paper assume that the conditions and rates under column III apply, i.e., an investor's long-term capital gains equal or exceed long-term capital losses and short-term capital gains equal or exceed short-term capital losses. To the extent this assumption is erroneous (and

\footnotetext{
${ }^{4}$ To illustrate, assume (a) long-term capital gains exceed long-term capital losses, (b) short-term capital losses exceed short-term capital gains, and (c) total (long plus short) capital gains exceed total (long plus short) capital losses. To compute taxable gain or loss, long-term capital gains are netted against long-term capital losses and short-term capital gains are netted against short-term capital losses. The resulting net long-term capital gains are furthered reduced by the net short-term capital losses, leaving a single gain amount that is taxed at the preferential long-term capital gains rate. Applying current rates, an additional dollar of long-term capital gains increases taxes by 20 cents because long-term capital gains, after all nettings, have risen by one dollar. However, an additional dollar of short-term capital gains also increases taxable income by 20 cents. The short-term gain reduces the amount by which the short-term losses exceed the short-term gains. Since short-term losses (net of short-term gains) offset long-term gains, an additional dollar of short-term capital gain increases net long-term capital gains by one dollar and taxes by 20 cents.
} 
certainly it is not true for many investors), we bias against rejecting the null hypothesis that taxes do not matter.

Even if some individuals could benefit from the preferential long-term capital gains tax rate by postponing (accelerating) the sale of appreciated (depreciated) stock, several additional conditions must hold for the long-term capital gains tax rate differential to alter share prices. Shackelford (2000) details the necessary conditions for a change in the capital gains tax rate differential to affect share prices. With slight modification, the same conditions must hold for static capital gains tax rates to affect equity values.

Briefly, the necessary conditions include the marginal investor being a compliant individual who intends to sell in a taxable transaction. His investment horizon must approximate the long-term holding period, which is currently one year. If his investment horizon is shorter, then the differential will not affect behavior. All gains and losses will be subject to short-term rates. If his investment horizon is longer, then the differential will not affect behavior. All gains and losses will be subject to long-term rates.

The tests in this study are predicated on the marginal investor being an individual who meets these conditions. To the extent this assumption is not true, we should fail to detect variation in price-earnings relations across different spreads in long-term and short-term capital gains tax rate regimes.

\section{HYPOTHESIS DEVELOPMENT}

This paper is guided by Shackelford and Verrecchia's (1999) (hereafter, SV) analysis of the impact of capital gains taxes on share price responses to public disclosures. Briefly, they construct a three-period model with two investor groups and two assets. The groups are 
identical, except that in the first period, each awaits a public disclosure, holding different weights of a taxable risky asset and a riskless, tax-free asset. In the second period the disclosure occurs, and investors rebalance their portfolio. In the third period the asset is liquidated, and the investors consume. The short-term capital gains tax rate applies to gains in the second period, and the tax-favored long-term capital gains tax rate applies to gains in the third period. SV conclude that the declining tax rates applied to capital gains will induce some investors to postpone sales from the second period to the third period. This tax-motivated restriction in equity capital gives the appearance of prices overreacting to the public disclosure.

To understand the intuition behind SV's analysis, assume a "good news" disclosure, i.e., one that causes the price of the risky asset to rise. If tax rates are constant (i.e., long-term capital gains tax rates equal short-term capital gains tax rates), then risk-averse investors who own the appreciated taxable risky asset will reduce the risk of an uncertain future by selling shares of the risky asset. However, if tax rates are declining (i.e., long-term capital gains tax rates are less than short-term capital gains tax rates), investors must choose between the reduced risk from selling and the reduced taxes from postponing the sale. As a result, investors unwind less of their positions at the disclosure than they would if rates were not declining. This equity shortage causes prices to rise, assuming the demand for the firm is downward sloping. The price appreciation is increasing in the spread between long-term and short-term capital tax rates. Alternatively stated, individual investors price shares as though they will face long-term capital gains tax treatment. To entice investors to sell before long-term qualification, buyers must compensate sellers for the additional taxes arising from short-term treatment.

Conversely, if the disclosure is "bad" news and tax rates are declining, investors benefit from accelerating their sales and generating tax-favored short-term capital losses. This results in 
more selling than would be undertaken if tax rates were constant over time. Equity expands and prices fall further. The price decline is increasing in the spread between long-term and shortterm capital tax rates. Alternatively stated, investors assume long-term capital loss treatment. To garner favorable short-term capital loss treatment, sellers are willing to accept a lower sales price. This leads to the first hypothesis, stated in alternative form:

$\mathrm{H}_{1}$ : With a good (bad) news disclosure, a firm's share price increases (decreases) in the difference between short-term capital gains tax rates and long-term capital gains tax rates.

In SV's stylized setting, fair market value equals tax basis before the disclosure. Thus, the disclosure provides the sole price movement and fully determines the taxable gain or loss. In reality, the gain or loss when shares are sold following a disclosure depends on the price changes created by both the disclosure and the stock's performance since the investor acquired the shares. If the share price appreciated before the disclosure, then selling at the disclosure triggers capital gains taxes arising from that appreciation. If the stock has not been held for the requisite longterm holding period, then the appreciation will be taxed as a disfavored short-term capital gain. Thus, conditional on the disclosure, the greater the past stock appreciation, the greater the taxes upon realization, and, assuming short-term capital gains, the greater the predicted stock price increase at disclosure.

Conversely, if the share price depreciated before the disclosure, then selling at the disclosure generates capital losses arising from depreciation before the disclosure. If the stock has not been held for the requisite long-term holding period, then the depreciation will be taxed as a tax-favored short-term capital loss. Thus, conditional on the disclosure, the greater the past stock depreciation, the greater the tax savings upon realization, and, assuming short-term capital 
losses, the greater the predicted stock price decrease at disclosure. Formally, the second alternative hypothesis can be stated as:

$\mathrm{H}_{2}$ : When a share is sold at disclosure, its price increases (decreases) in the incremental taxes (tax savings) generated from the short-term capital gains (losses) on its past price appreciation (depreciation).

To summarize, the first hypothesis states that tax incentives to defer selling following good news (and accelerate selling following bad news) affects price responses to disclosures. The second hypothesis adds that trading following a disclosure will be further impacted by the firm's past price performance. That is, selling appreciated (depreciated) stocks will trigger taxable gains (losses), whether the disclosure is good or bad news.

\section{PRIMARY EMPIRICAL ANALYSIS}

\section{Research Equation}

SV propose, but do not undertake, a test of their theory using stock price reactions around the release of quarterly earnings announcements. To undertake such a test, we estimate equation

$$
\begin{aligned}
C A R_{i t}= & \beta_{0}+\beta_{1} U E_{i t}+\beta_{2} \Delta P A S T_{i t}+\beta_{3} D_{R A T E_{t}}+\beta_{4} U E_{i t} * D R A T E_{t}+\beta_{5} \Delta P A S T_{i t} * D R A T E_{t} \\
& +\sum_{j=83}^{96} \beta_{6 j} Y E A R_{t}+\sum_{j=83}^{96} \beta_{7 j} U E_{i t} * Y E A R_{t}+\varepsilon_{i t}
\end{aligned}
$$

where: $C A R_{i t}=$ firm i's three-day, cumulative, buy-and-hold abnormal return, beginning on day $t-1$, where $t$ is the day that earnings are announced;

$U E_{i t}=$ reported quarterly earnings for firm i on day $\mathrm{t}$ less the median IBES forecast within the 60 days preceding day $t$, scaled by firm i's share price at the end of the quarter including day $t$;

$\triangle P A S T_{i t}=$ the difference between firm i's stock price at day $\mathrm{t}-1$, adjusted for stock splits and stock dividends, and its stock price at day $\mathrm{t}-\mathrm{n}$ when $\mathrm{n}$ is the number of days in the holding period on day $t$, divided by its stock price at day $\mathrm{t}-\mathrm{n}$; 


$$
\begin{aligned}
& D R A T E_{t}=\text { the maximum statutory short-term capital gains tax rate less the } \\
& \text { maximum statutory long-term capital gains tax rate on day } t \text {; } \\
& Y E A R_{t}=\text { categorical variable that equals one if day } \mathrm{t} \text { is in year } \mathrm{j} \text {, where } \mathrm{j}=1983 \\
& \text { to } 1996 .
\end{aligned}
$$

A positive coefficient on $U E * D R A T E$ is consistent with the first alternative hypothesis, i.e., earnings response coefficients vary with the spread between short-term and long-term capital gains tax rates. A positive coefficient on $\triangle P A S T^{*} D R A T E$ is consistent with the second alternative hypothesis, i.e., tax implications associated with the prior price movements affect the price response when earnings are released.

\section{Sample}

All 97,478 firm-quarters from 1983-1997 on CRSP, IBES, and Compustat's industrial annual, full coverage, and research files are examined. Firms are deleted from the final sample if data are missing $(1,338), U E$ are zero $(7,589)$, stock prices do not change over the holding period $(5,238)$, or earnings are negative $(11,942) .^{5}$ The final sample includes 71,371 observations. Table 2 presents descriptive statistics and Pearson and Spearman correlation coefficients for the regression variables.

\footnotetext{
${ }^{5}$ By eliminating companies with zero $U E$, we eliminate firms for which no price movement is anticipated. By eliminating companies with zero $\triangle P A S T$, we reduce the risk that our sample includes firms that are inefficiently priced because of thin markets. We drop loss firms because Hayn (1995) documents that earnings response coefficients are significantly different between profitable and loss firms. Results, however, are qualitatively unaltered if these screens are ignored.
} 


\title{
Explanatory variables
}

\author{
$U E$ and $Y E A R$
}

A positive regression coefficient estimate is anticipated on $U E$, consistent with the welldocumented positive correlation between abnormal returns and unexpected earnings. ${ }^{6}$ Besides its interaction with DRATE, which provides one of the two variables of interest, $U E$ is also interacted with a yearly indicator variable $(Y E A R)$. The year interaction is intended to control for a steady increase in earnings response coefficients during the investigation period, as documented in McKeown and Raedy (2000). YEAR also is separately included in the regression to control for any other possible sources of variation across years.

\section{$\triangle P A S T$}

Past price performance is measured as the percentage change in stock prices during the previous six, 12 or 18 months. The applicable duration depends on the long-term capital gains holding period at the time of the earnings release. Table 1 shows the holding period during the investigation period. We assume the holding period is one year for all days, except June 23, 1985 through June 30, 1988, when it is six months, and July 29, 1997 through December 31, 1997, when it is 18 months. $^{7}$

\footnotetext{
${ }^{6}$ Extreme values of $U E$ are winsorized at the 1 percent and 99 percent levels.

${ }^{7}$ Throughout the investigation period, the long-term capital gains holding period is determined by the date of sale with one exception. The holding period is six months for assets purchased after June 22, 1984 and before January 1, 1988. Therefore, it is unclear whether investments sold from December 24, 1984 through June 22, 1985 face the new six-month holding period or the prior 12-month holding period. We assume a 12-month holding period; however, results are qualitatively insensitive to assuming a 6-month holding period. Similarly, sales during the first half of 1988 may have faced either a six-month holding period or a 12-month holding period. Because no sale during the first half of 1988 could have qualified for long-term treatment unless it had been purchased before 1988 and thus faced a six-month holding period, we assume a six-month holding period for all sales in the first half of 1988. Note that during the second half of 1988, no investments shifted from short-term to long-term status. Assets purchased in 1988 faced a 12-month holding period, which could not lapse until 1989. Assets purchased before 1988 had already qualified for long-term treatment by July 1, 1988. This apparent measurement problem is diminished in this study because the rate differential during 1988 was zero. However, to ensure that this unusual
} 
This duration is selected because the difference between long-term and short-term rates is most relevant for investors who are near long-term qualification at disclosure. Thus, $\triangle P A S T$ is computed as though the marginal investor is an individual who has held the stock for precisely one day less than necessary to obtain long-term capital gains tax treatment. Such an individual would have the greatest incentive to postpone a sale and receive long-term capital gains tax treatment or to accelerate a sale and receive short-term capital loss tax treatment.

We expect the coefficient on $\triangle P A S T$ will be positive for at least two reasons. First, Jegadeesh and Titman (1993), Bernard, Thomas and Wahlen (1998) and Raedy (2000), among others, show that stocks that experience short-term positive (negative) returns will continue to experience positive (negative) returns for the next few quarters. To the extent such price momentum exists, a positive relation is expected between price movements in the three-day window around the earnings announcements and price movements in the preceding holding period.

Second, to the extent prices have risen during the holding period, tax costs associated with selling have increased, even for investors unaffected by the long-term/short-term capital gains tax tradeoffs investigated in this paper. For example, when prices are rising, an individual who has held shares for more than the long-term holding period faces increasing long-term capital gains taxes. Thus, he demands additional compensation to cover the additional taxes, potentially resulting in a seller's strike and further price increases. Although different from the tax effect examined here, this price pressure from this "lock-in" effect may induce a positive coefficient on $\triangle P A S T$. For these two reasons, we include $\triangle P A S T$ as a separate explanatory 
variable, ensuring that these potential effects do not impact the interpretation of the variables of interest. $^{8}$

\section{DRATE}

The ideal tax measure would capture the change in capital gains taxes, if any, that individual shareholders encounter if they sold shares at the disclosure date rather than in the future when the long-term rate applies. Unfortunately, we cannot observe individual investors' marginal tax rates, holding periods, or total portfolio of realized gains and losses, all of which are necessary to compute the ideal tax measure.

Instead we employ a cruder measure, the difference in short-term capital gains tax rates and the long-term capital gains tax rates at disclosure, assuming long-term capital gains equal or exceed long-term capital losses and short-term capital gains equal or exceed short-term capital losses. Using the spreads for this assumption in Table 1, column III, DRATE is 30 from 19831987, 10.5 in 1987, 0 from 1988-1990, 3 from 1991-1992, 11.6 from 1993 to May 6, 1997, and 19.6 since then. No prediction is advanced for the coefficient on DRATE, when it is included separately in the regression. The sole purpose for its inclusion is to ensure that any unspecified variation in DRATE does not affect the interpretation of the interaction coefficients. ${ }^{9}$

The variables of primary interest in this study are DRATE interacted with $U E$ and $\triangle P A S T$. Both interaction coefficients are predicted to be positive.

\footnotetext{
${ }^{8}$ Inferences concerning the sign and overall significance of the variables of interest are unchanged if $\triangle P A S T$ is excluded from the regression. However, the coefficient on $\triangle P A S T * D R A T E$, one of the two variables of interest, becomes much larger and more significant if $\triangle P A S T$ is dropped.

${ }^{9}$ Inferences are unchanged if $D R A T E$ is excluded from the regression.
} 


\section{Results}

Table 3, column A presents estimated coefficients from the ordinary least squares regression using the quarterly earnings announcement sample (year intercepts and their interaction with unexpected earnings are not tabulated). ${ }^{10}$ The findings are consistent with individual investors' capital gains taxes affecting share price responses to earnings

announcements. The results suggest that the large body of accounting research that examines share price reactions to financial reporting disclosures may omit an important price determinant, shareholders' capital gains taxes.

As predicted, the coefficients on both interactions are positive, consistent with share prices increasing in capital gains taxes. Review of the other coefficients reveals that the coefficients on $U E$ and $\triangle P A S T$ are positive, as expected. The coefficient on DRATE, for which no prediction is offered, is not significantly different from zero.

The coefficient on $U E * D R A T E$ is significantly greater than zero at the 0.05 level, using a one-tailed test. The economic significance implied by the coefficient is non-trivial. A one standard deviation increase in $U E * D R A T E$ increases three-day cumulative abnormal returns by 0.21 percentage points (18 percent annualized) or a 71 percent increase in returns for the mean firm. ${ }^{11}$ In other words, conditional on the price implications of altering $U E, D R A T E$ or any

\footnotetext{
${ }^{10}$ The empirical results do not appear to suffer from cross-sectional dependence for two reasons. First, by examining returns from three-day windows, we avoid the cross-sectional dependence problems typically associated with long windows, such as one quarter or one year (Bernard 1987). Second, cross-sectional dependence problems typically cluster in intra-industry analysis as opposed to inter-industry analysis (Bernard 1987). The sample in this study includes 262 three-digit SICs; only six of which represent more than $2 \%$ of the sample. Furthermore, when we exclude firms that announce earnings on the same day as three or more firms in their three-digit SIC, leaving 60,642 observations, results are qualitatively unchanged. On the other hand, multicollinearity, which exists between $D R A T E$ and the year indicator variables (e.g., multiple variance inflation factors exceed 10 and the condition indexis 24), may be a serious econometric problem, inflating standard errors and biasing against rejecting the null hypothesis that taxes do not matter. To address the stability of the regression coefficients, we reestimate the model, dropping DRATE . Results are qualitatively unaltered. Finally, we control for nonlinearities in the returnearnings relation using the approach in Lipe, Bryant and Widener (1998). Again, conclusions are unchanged. ${ }^{11} 0.21$ percentage points are the product of $\triangle R A T E * U E$ 's standard deviation of 0.00145 and its regression coefficient estimate of 1.475 . 71 percent is the 0.21 percentage points divided by the mean $C A R$ of 0.003 .
} 
other explanatory variable, a one standard deviation increase in the interaction enhances equity returns by 71 percent.

This finding is consistent with individual investors demanding compensation for the additional short-term capital gains (or reduced short-term capital losses) created by good news disclosures. Likewise, it is also consistent with individual investors accepting lower share prices to garner the additional short-term capital losses (or reduced short-term capital gains) created by bad news disclosures.

The coefficient on $\triangle P A S T^{*} D R A T E$ is significantly greater than zero at the 0.001 level. Using the same computation as above, a one standard deviation increase in $\triangle P A S T * D R A T E$ increases three-day cumulative abnormal returns by 0.13 percentage points ( 11 percent annualized) or a 45 percent increase in returns for the mean firm. This finding is consistent with buyers compensating individuals for the short-term capital gains that they incur on the appreciation in their shares before the earnings announcement. It also is consistent with individuals accepting less compensation because they enjoy favorable short-term capital losses on the sale of depreciated shares.

\section{Sensitivity Tests}

The results are robust to several sensitivity tests. First, to test the robustness of the $\triangle P A S T^{*} D R A T E$ results, we segregate the sample into three periods based on the spread between short-term and long-term capital gains tax rates (see Table 1, column III): (a) when the spread is zero or three (1988-1992), (b) when the spread is greater than 10 and less than 20 (1987, 1993-1997), and (c) when the spread is 30 (1983-1986). The regression is then estimated separately for each period with only two explanatory variables, $U E$ and $\triangle P A S T$. 
If price responses vary with past prior performance, we would expect the coefficients on $\triangle P A S T$ to be increasing in the long-term capital gains tax differential. Consistent with this prediction, we find that the coefficient on $\triangle P A S T$ is largest when the spread is 30 . It is double the smallest coefficient, which occurs when the spread is zero or three. Unfortunately, the increase in earnings response coefficients over the investigation period prevents repeating this robustness check for the $U E * D R A T E$ result.

Second, to ensure that the results are not solely driven by the three years when short-term rates equal long-term rates (1988 to 1990), we reestimated equation (1) without those years. Conclusions are qualitatively unaltered. Third, during the fourth quarter of 1986, extraordinary levels of capital gains were realized in anticipation of the 1987 increase in long-term capital gains tax rates. When earnings releases in the fourth quarter of 1986 are excluded from the study, inferences are qualitatively unaltered.

Fourth, an individual's marginal tax rate for capital gains and losses is determined annually. Thus, tax planning could become more precise as individuals near year-end. However, we find no such evidence. Inferences are qualitatively unchanged when disclosures in December are deleted from the study and when disclosures in October, November, and December are deleted from the study.

\section{ADDITIONAL EMPIRICAL ANALYSES}

The remainder of the paper extends the analysis of capital gains taxes and equity pricing in four directions. First, to mitigate any concerns that earnings announcements release unspecified information that the earlier tests might misconstrue as capital gains tax effects, we replicate the tests in a different disclosure setting — when stocks are added to the Standard \& 
Poor's 500. Second, we test whether capital gains tax effects are detected in trading volume around earnings announcements. In both extensions, we find capital gains tax effects related to past price performance, but not the information from the disclosure.

Third, we test whether companies held predominantly by individuals are marked by more pronounced capital gains tax effects. We find limited evidence that results vary with ownership structure, however, this test is hampered by an inability to measure individual ownership precisely. Finally, we test whether prices revert back to their original levels in the days following the earnings announcement or inclusion in the S\&P 500. Some price reversion is detected.

\section{Standard \& Poor's 500 Additions}

One possible explanation for the findings is that earnings announcements release unspecified information that this study mischaracterizes as capital gains tax effects. To address this concern, we repeat the analysis with a different public disclosure, the announcement that a firm will be added to the S\&P 500 .

This is a particularly attractive setting for conducting a robustness check for at least three reasons. First, the announcement provides no information about the taxes of the firm or its shareholders. In fact, many studies of S\&P 500 additions are motivated by an assumed absence of any information, tax or otherwise (e.g., Harris and Gurel 1986 and Shleifer 1986). Second, S\&P 500 firms should be among the most efficiently priced in the world. They are the largest U.S. companies, publicly-traded, and closely followed by many analysts. Third, non-individuals (particularly institutions) have large stockholdings in these firms. The impact of individual taxation of capital gains and losses should be less for these companies than others. 
Because S\&P 500 index funds commit to investing in such firms, overall demand should increase when Standard \& Poor's announces that it is adding a firm to the index, consistent with Harris and Gurel (1986) and Shleifer (1986). ${ }^{12}$ An increase in demand should boost share prices, i.e., joining the index should be good news. If the difference in short-term and long-term capital gains tax rates affects equity values, then stock price changes should reflect the compensation that index funds provide individual investors to entice them to sell at the tax-disfavored shortterm capital gains tax rate.

To test whether capital gains tax incentives affect price responses to inclusion in the S\&P 500, we reestimate equation (1) with two modifications. First, consistent with Shleifer's (1986) S\&P 500 study, the dependent variable is firm i's five-day, cumulative, buy-and-hold abnormal returns, beginning on day $t$, where $t$ is the first trading day following the announcement.

Because the S\&P announces additions to the index after the market closes, we begin our computation of cumulative abnormal returns on the following day. Abnormal returns range from -27 percent to 34 percent with a mean and median of 4 percent.

Second, unexpected earnings ( $U E$ ) is replaced with a measure of the demand by index funds for a firm when it joins the S\&P 500. JOIN is the percentage of equity mutual fund assets Money (April 1999, p.102). ${ }^{13}$

Consistent with a dramatic increase in the number and holdings of S\&P 500 index funds during the investigation period, JOIN increases steadily from 0.2 percent in 1978 to 6.5 percent in

\footnotetext{
${ }^{12}$ In theory, deletions from the S\&P 500 should have the opposite effect. However, most deletions concern unusual transactions, such as mergers, acquisitions, bankruptcy, or other liquidations. Thus, consistent with prior studies, we restrict the analysis to additions.

${ }^{13}$ Results are qualitatively unaltered if alternative measures of price pressure from index funds are used, including Vanguard's number of index funds, Vanguard's percentage of assets in index funds, and natural logarithm of Vanguard's index fund assets, all as reported in Bogle (1999).
} 
1998. The percentage decreased in only two years, 1983 and $1986 .{ }^{14}$ As index funds have become more active in the equity markets, the price pressure from joining the S\&P 500 should have increased accordingly. Therefore, a positive coefficient is expected on JOIN when it is included as a separate regressor, indicating increased upward price pressure in recent years, ignoring any tax effects.

All other variables remain unaltered. The variables of interest remain two interactions, $J O I N * D R A T E$ and $\triangle P A S T * D R A T E$. Coefficients on both are expected to be positive.

We purchased from Standard \& Poor's a list of the 473 firms added to the S\&P 500 from January 1, 1978 to December 31, 1998. From the Standard \& Poor's list, we delete 62 additions attributable to restructurings of existing S\&P 500 firms and 12 additions for which data are missing. The final sample includes 399 S\&P 500 additions. Four firms are included twice in the sample. Annual additions range from 6 in 1992 to 33 in 1998. Before 1990, S\&P 500 announcement and addition dates were identical. Since 1990, the announcement has preceded the addition by seven days, on average, but the lapse has been as great as 100 days. Table 4 presents descriptive statistics and Pearson and Spearman correlation coefficients for the regression variables used in the S\&P 500 tests.

Table 3, column B presents the regression coefficient estimates from estimating equation (1) for the $\mathrm{S} \& \mathrm{P}$ additions. Contrary to expectations, the coefficient on $J O I N * D R A T E$ is negative, though not significantly different from zero. This finding provides no evidence that individual investors demand compensation for the additional short-term capital gains created by

\footnotetext{
${ }^{14}$ The steady increase in JOIN creates extreme multicollinearity, which we address by dropping the year indicator variables from the model. Consequently, besides capturing the intended increase in demand from S\&P 500 index funds over time, the coefficient on JOIN may capture other unspecified intertemporal changes. The other intertemporal institutional change that we are aware is that before 1990 announcements coincided with additions to the index. Now announcements precede additions by several days.
} 
the price increase from joining the index.

Consistent with predictions, the coefficient on $\triangle P A S T^{*} D R A T E$ is positive and significant at the 0.01 level. A one standard deviation increase in $\triangle P A S T * D R A T E$ boosts fiveday cumulative abnormal returns by 1.2 percentage points (60 percent annualized) or a 27

percent increase in returns for the mean firm. This finding is consistent with buyers compensating individuals for the short-term capital gains that they incur on the appreciation in their shares before the disclosure. It also is consistent with individuals accepting less compensation because they enjoy favorable short-term capital losses on the sale of depreciated shares. In either case, the results imply that individual investors' capital gains taxes affect prices when firms join the S\&P 500 index. ${ }^{15}$

Review of the other coefficients reveals that the intercept is positive, indicating a general price increase when a firm enters the S\&P 500. As predicted, the coefficient on JOIN also is positive, consistent with the price pressure increasing as index funds have grown. Contrary to expectations, the coefficient on $\triangle P A S T$ is negative. ${ }^{16}$ The coefficient on $\triangle R A T E$, for which no prediction is offered, is not significantly different from zero. Results are uniformly robust to sensitivity tests similar to those conducted for the earnings announcements tests.

\footnotetext{
${ }^{15}$ One possible reason why the results for the past price performance are stronger than the results for the response to joining the index is that past price movements are larger and more important from a tax perspective than the price movements at announcement. Theoretically, if capital gains tax rate differentials affect stock prices, then price movements created from both the announcement and the past should affect share responses. However, except under the most unusual conditions, a single disclosure will not move prices as much as the cumulative effect of the previous six to eighteen months of trading. Thus, the tax effect from the past appreciation or depreciation likely dominates the tax effects from the immediate disclosure.

${ }^{16}$ One reason why the coefficient on $\triangle P A S T$ could be negative is leakage associated with $\mathrm{S} \& \mathrm{P}$ additions in the earlier years of the investigation period. As discussed above, before 1990, the S\&P added firms on the day of the announcement. Reportedly, investors speculated about future additions to the index (New York Times, May 21, 1986). If so, the $\triangle P A S T$ measurement period may include price increases attributable to speculation about a firm joining the index. Consistent with this explanation, $\triangle P A S T$ is not significantly different from zero if the $\triangle P A S T$ measurement period concludes one month preceding the S\&P 500 announcement or if years before 1990 are excluded from the study. Of more relevance to this study, inferences on the interactive variables of interest hold under these alternative specifications.
} 
This S\&P 500 extension confirms that the price determinant captured in the $\triangle P A S T^{*} D R A T E$ coefficient is not unique to earnings releases. The results show that share prices are increasing (decreasing) around both earnings announcements and S\&P 500 additions in years when the spread between long-term and short-term rates is greatest for firms with the most appreciation (depreciation) during the previous six to 18 months. Unable to identify any other reason for this relation, we conclude that this determinant is the impact of the long-term capital gains tax differential.

\section{Trading Volume around Earnings Announcements}

The next extension shifts from stock return analysis to trading volume analysis. SV predict that differential capital gains tax rates cause trading volume to move inversely with prices. That is, individual shareholders respond to good news by withdrawing from the equity markets to await long-term treatment, causing prices to rise. Thus, trading volume decreases create price increases. Likewise, bad news creates incentives to sell and realize short-term capital losses. Thus, trading volume increases create price decreases.

Suppose tax-exempt organizations, tax-deferred pension plans, individuals' whose shares already qualify for long-term capital gains treatment, foreign investors, and others unaffected by long-term capital gains differentials can fully supply the shares to meet demand when earnings are released. Then sellers will not face incremental short-term capital gains, and the above results apparently relate to some other unspecified price determinant. Conversely, if sellers do face incremental short-term capital gains taxes (i.e., long-term capital gains tax differentials matter to the marginal investor), then trading volume should vary as SV predict. In other words, 
trading volume is another venue for testing whether spreads in long-term and short-term capital gains taxes affect the equity markets.

To test whether capital gains tax incentives affect trading volume when earnings are announced, we reestimate equation (1) substituting abnormal volume $\left(A V_{i t}\right)$ as the dependent variable. Abnormal volume is the firm i's average volume over days $\mathrm{t}-1$, $\mathrm{t}$, and $\mathrm{t}+1$ less the median volume for the 100 days preceding day $\mathrm{t}-1$, where volume is trading volume divided by shares outstanding. Mean (median) abnormal volume is $0.004(0.001)$ with a standard deviation of 0.011 (Table 2, panel A). ${ }^{17}$ The variables of interest remain the interactions with the longterm differential rate, $U E * D R A T E$ and $\triangle P A S T * D R A T E$. However, these coefficients are now predicted to be negative.

Table 3, column C presents estimated coefficients from the trading volume regression. ${ }^{18}$ As in the S\&P 500 extension, the coefficient on $U E * D R A T E$ has the wrong sign, though not significantly different from zero. This result provides no evidence to support capital gains taxes affecting trading volume.

On the other hand, as predicted, the coefficient on $\triangle P A S T^{*} D R A T E$ is negative and significantly less than zero at the 0.001 level. This finding is consistent with individual holders of appreciated (depreciated) stock restricting (expanding) the supply of equity more in years with larger long-term capital gains tax differentials. Economic significance, however, is modest. A one standard deviation increase in $\triangle P A S T^{*} D R A T E$ increases three-day cumulative abnormal volume by 8 percent for the mean firm. Results are robust to the sensitivity tests conducted using returns.

\footnotetext{
${ }_{17}^{17}$ Conclusions are unchanged if abnormal volume is winsorized at the 1 percent and 99 percent levels.

${ }^{18}$ To test whether asymmetric volume responses to price increases versus price decreases (Karpoff, 1987, Bamber and Cheon, 1995) affect the conclusions in this paper, a categorical variable indicating the sign of the three-day raw return surrounding the earnings announcement is added as an explanatory variable. Inferences are unaltered.
} 
The capital gains tax incentives examined in this paper should not affect trading volume around S\&P 500 additions because index funds must acquire shares and will bid up the price until shares trade. Thus, we predict that S\&P 500 additions increase trading volume, but that volume does not vary for tax reasons. Consistent with this prediction, when we reestimate the trading volume equation using S\&P 500 additions, trading volume increases with the growth of index funds (the coefficient on $J O I N$ is positive and significant with a t-statistic of 2.4), but the coefficients on the interactions are not significantly different from zero. Table 3 , column $\mathrm{C}$ shows the coefficient on $U E * D R A T E$ is 0.005 ( $t$-statistic of 1.15). The coefficient on $\triangle P A S T^{*}$ DRATE is -0.002 ( $t$-statistic of -0.26$)$.

\section{Individual Ownership}

The third extension evaluates another SV prediction. SV show that the tax-motivated response to disclosures should be greatest among companies held by individual investors subject to differential capital gains tax rates. Unfortunately, determining the extent to which individuals hold taxable shares is problematic. The capital gains and losses on individuals' tax returns are affected by many investments, including personal holdings, street-name holdings, trusts, mutual funds, partnerships, S corporations, limited liability corporations, and other entities that passthrough taxable gains and losses. Individuals also hold shares through many accounts that are unaffected by the long-term rate differential, such as closely-held C corporations, individual retirement accounts, 401(k) retirement accounts, and other defined contribution plans.

Because publicly available data lack sufficient detail for us to identify taxable individual shareholdings with precision, we resort to a categorical variable from Spectrum. IND equals one if 75 percent of firm i's shares on day t are owned by non-institutions and zero otherwise. 
$I N D$ is interacted with all of the other explanatory variables, except the year indicator variables.

Including $I N D$ and its interactions modifies the original regression equation as follows:

$$
\begin{aligned}
& C A R_{i t}=\beta_{0}+\beta_{1} U E_{i t}+\beta_{2} \Delta P A S T_{i t}+\beta_{3} D_{R A T E}+\beta_{4} U E_{i t} * D R A T E_{t}+\beta_{5} \Delta P A S T_{i t} * D R A T E_{t} \\
& +\sum_{j=83}^{96} \beta_{6 j} Y E A R_{t}+\sum_{j=83}^{96} \beta_{7 j} U E_{i t} * Y E A R_{t}+\beta_{8} I N D_{i t}+\beta_{9} I N D_{i t} * U E_{i t} \\
& +\beta_{9} I N D_{i t} * \Delta P A S T_{i t}+\beta_{10} I N D_{i t} * D R A T E_{t}+\beta_{11} I N D_{i t} * U E_{i t} * D R A T E_{t} \\
& +\beta_{12} I N D_{i t} * \Delta P A S T_{i t} * D R A T E_{t}+\varepsilon_{i t}
\end{aligned}
$$

Positive coefficients on $\beta_{11}$ and $\beta_{12}$ will be interpreted as evidence that capital gain taxes affect prices more in companies held mostly by individuals.

Table 5 reports selected regression coefficients from estimating equation (2). When the dependent variable is cumulative abnormal returns around earnings announcements, $\beta_{11}$, the coefficient on $I N D^{*} U E^{*}$ DRATE is positive and weakly significant (t-statistic of 1.7$)$. This is consistent with the cumulative abnormal returns around earnings releases increasing more in unexpected earnings when the long-term capital gains tax differential is largest and the firm is mostly owned by individuals. Conversely, $\beta_{12}$, the coefficient on $I N D^{*} \triangle P A S T^{*} D R A T E$, is negative, providing no evidence that this relation holds for past stock performance.

When the abnormal returns around S\&P 500 additions are examined, $\beta_{11}$ is again positive and significant ( $t$-statistic of 2.0), further evidence that the tax-induced response to the disclosure is greatest in companies controlled by individuals. $\beta_{12}$ is positive, but not significantly different from zero.

When the dependent variable is abnormal volume, the pattern reverses. The sign of $\beta_{11}$, the coefficient on $I N D^{*} U E^{*} D R A T E$, is now contrary to expectations. Conversely, $\beta_{12}$, the coefficient on $I N D^{*} \triangle P A S T^{*} D R A T E$, is now significant $(t$-statistic of -2.0$)$ in the predicted 
direction (negative). The $\beta_{12}$ result is consistent with trading volume around earnings releases increasing more in the incremental taxes from past performance for firms held mostly by individuals.

In summary, we find mixed support for individual ownership affecting the capital gains tax influence on price and volume around public disclosures. Measurement error likely weakens the power of these tests. For instance, Spectrum classifies taxable individual mutual fund accounts as institutional holdings. Thus, in an attempt to identify a more precise measure, we conducted additional tests using a Spectrum's indicator variable equaling one when individuals and mutual funds combined control at least 75 percent of the shares. Results remain murky. Likewise, we used a firm's dividend yield, which should be inversely related to taxable individual ownership. It also produces conflicting results.

\section{Price Reversion}

SV are silent on whether the price changes at the time of public disclosure are permanent or temporary. However, if prices move because capital gains taxes create a temporary shortage (or excess) of sellers, then prices should revert back to original levels at some point. The problem in constructing a test of price reversion is determining when reversion should be expected. Because we are unable to specify how quickly investors unaffected by long-term capital gains rate differentials can reestablish prices at their original level, we assert no hypothesis about price reversion and are cautious to infer price reversions from the data. Nevertheless, an examination of post-disclosure abnormal returns produces regression coefficient estimates consistent with at least some price reversion in the days following the disclosure. 
Table 6 reports results for the price reversion tests. For earnings releases, we reestimate equation (1), substituting three-day cumulative abnormal returns for the days immediately following the period examined above, i.e., days $t+2$ through $t+4$. All other variables are retained and measured identically. If price reversion occurs, we would expect the coefficients on the interactions (UE* DRATE and $\left.\triangle P A S T^{*} D R A T E\right)$ to be of opposite sign from the original regression, i.e., negative.

Consistent with a rebound, column A's coefficient on $U E * D R A T E$ is negative and significant at 0.01 . The regression coefficient estimate is slightly larger than the coefficient from the original model, implying that price fully rebounds from this effect in three days. However, by the sixth post-announcement date, cumulative abnormal returns associated with the coefficient on $U E * D R A T E$ are no longer significantly less than zero at the 10 percent level. They remain insignificant at the end of the first ten post-announcement period trading days (column B). In other words, it appears that prices fully rebound within three days from the $U E * D R A T E$ price effect and then stabilize.

Conversely, column A's coefficient on $\triangle P A S T * D R A T E$ is positive after three postdisclosure trading days. This is not consistent with an immediate price rebound. However, an analysis of daily, noncumulative returns reveals that for five of the next seven days, the coefficient is negative. In fact, the coefficient on $\triangle P A S T^{*} D R A T E$ for days $\mathrm{t}+5$ through $\mathrm{t}+7$ is significantly less than zero, consistent with a delayed price reversion. Column B shows that the coefficient on $\triangle P A S T^{*} D R A T E$ for the 10 days following the disclosure period is negative $(-0.008)$, though not significant at conventional levels ( $t$-statistic of -1.1). Thus, it appears that price reversion from the $\triangle P A S T^{*} D R A T E$ effect is limited and lags the reversion from the $U E * D R A T E$ effect. 
For S\&P 500 additions, we substitute five-day cumulative abnormal returns for the days immediately following the period examined above, i.e., days $t+5$ through $t+9$. All other variables are retained and measured identically. If price reversion occurs, we would expect the coefficient on $\triangle P A S T * D R A T E$ to be of the opposite sign from the original regression, i.e., negative. ${ }^{19}$

Column $\mathrm{C}$ shows that the coefficient on $\triangle P A S T^{*} D R A T E$ is negative, as predicted, and significant at the 0.05 level using a one-tailed test. The coefficient estimate is roughly half its value in the original regression, suggesting that prices revert after five days to about half the original level. Additional analysis of days $t+10$ through $t+14$ reveals no further price reversion associated with $\triangle P A S T^{*} D R A T E$. Column D adds that the coefficient on $\triangle P A S T T^{*} D R A T E$ for the ten trading days following the post-announcement period is not significantly different from zero.

\section{CLOSING REMARKS}

This paper produces evidence consistent with the difference between long-term and short-term capital gains tax rates affecting stock prices around public disclosures. Specifically, we find that price responses to quarterly earnings releases are increasing in the additional taxes that investors would pay under short-term capital gains tax treatment. Similar findings related to the firm's past price performance are detected for returns around a firm's addition to the S\&P 500 and for trading volume around earnings announcements.

The strongest results throughout the analysis generally come from the interaction $\triangle P A S T * D R A T E$. We conclude that the results are generally consistent with individual investors demanding compensation for the incremental taxes created by selling appreciated

\footnotetext{
${ }^{19}$ No price reversion is expected for the coefficient on JOIN *DRATE because this interaction is not significant during the disclosure period.
} 
shares before they qualify for long-term treatment. The findings also are consistent with individuals accepting reduced prices on depreciated shares because they trigger favorable shortterm capital losses.

The primary contribution of this study is its documentation that capital gains taxes affect share prices around earnings announcements. Unlike prior studies that have focused on price reactions in settings where shareholder taxes might be unusually salient (e.g., tax law changes, turn-of-the-year trading, or tax-sensitive transactions), this study finds the imprint of capital gains taxes in more generalized settings. This paper documents a pervasiveness to the capitalization of capital gains taxes that previous studies could not infer.

The findings in this study should interest scholars and practitioners interested in both firm valuation and taxation. In addition, the findings should contribute to ongoing policy debates about capital gains tax policy, one of the least stable and most controversial aspects of the tax law. For example, the results are suggestive about the lock-in effect. Among other implications, the lock-in effect gives investors an incentive to avoid long-term capital gains by holding stocks until death. The results in this paper would suggest that some investors may demand compensation for long-term capital gains taxes as enticement to sell shares before death.

Two directions for future research seem promising. First, this study's inability to find less ambiguous tax responses for companies held by individuals is troubling. Although measurement error most likely accounts for the failure to reject the null hypothesis, finding variation by shareholder-types would greatly strengthen our confidence in the conclusions drawn from this study.

Second, this study shows that capital gains taxes affect trading even when disclosures are not about taxes. A next step is to extend this study to investigate trading in settings where no 
firm-specific information is being disclosed. Individuals face capital gains or losses with every trade. Each day a steady flow of shares qualifies for favorable long-term capital gains tax treatment at every firm. Learning whether capital gains tax effects can be detected in normal daily trading would be an important extension to the emerging literature linking equity prices and shareholder taxes.

Finally, this paper contributes to the growing documentation that investor-level taxes affect stock prices (Guenther and Willenborg 1999; Collins and Kemsley 2000; Lang and Shackelford 2000; among others). These findings are important, partly because they are inconsistent with an assumption underpinning the prominent valuation models in accounting research (e.g., Edwards-Bell-Ohlson's residual income valuation, discounted cash flows or dividends, capital asset pricing models, arbitrage pricing models). Typically these theoretical models and the empirical tests that rely on them ignore shareholder taxes. The recent findings, to which this paper contributes, suggest that shareholder taxes may be an important factor in equity valuation. Similarly, these findings may imply that accounting courses, such as financial statement analysis, and popular valuation texts (e.g., Palepu, Bernard and Healy, 1996) should consider incorporating investor-level taxes in their analyzes. 


\section{References}

Amoako-Adu, B., M. Rashid, and M. Stebbins. 1992. Capital gains tax and equity values:

Empirical test of stock price reaction to the introduction and reduction of capital gains tax exemption. Journal of Banking and Finance 16: 275-287.

Ayers, B., Lefanowicz, C., and J. Robinson. 2000. The effects of goodwill tax deductions on the market for corporate acquisitions. Journal of American Taxation Association, Supplement, forthcoming.

Bamber, L. and Y. Cheon. 1995. Differential price and volume reactions to accounting earnings announcements. The Accounting Review 70: 417-441.

Berger, P. 1993. Explicit and implicit tax effects of the R\&D tax credit. Journal of Accounting Research 31: 131-171.

Bernard, V. 1987. Cross-sectional dependence and problems in inference in market-based accounting research. Journal of Accounting Research 25: 1-48.

, J. Thomas, and J. Wahlen. 1997. Accounting-based stock price anomalies: Separating market inefficiencies from risk. Contemporary Accounting Research 14: 89-136.

Blouin, J., J. Raedy, and D. Shackelford. 1999. Stock prices and capital gains taxes: Evidence from the 1998 reduction in the long-term capital gains holding period, Working paper, University of North Carolina, Chapel Hill, NC.

Bogle, J. 1999. The first index mutual fund: A history of Vanguard index trust and the Vanguard index strategy, Vanguard web site, http://www.vanguard.com.

Collins, J., J. Hand, and D. Shackelford. 2000. Valuing deferral: The effect of permanently reinvested foreign earnings on stock prices. In International Taxation and Multinational Activity, ed. Hines, J., (Chicago: University of Chicago Press), forthcoming. , and D. Kemsley. 2000. Capital gains and dividend capitalization in firm valuation: Evidence of triple taxation. Working paper, University of North Carolina, Chapel Hill, NC.

Dhaliwal, D. and R. Trezevant. 1993. Capital gains and turn-of-the-year stock price pressures. Advances in Quantitative Analysis of Finance and Accounting 2: 139-154.

Engel, E., M. Erickson, and E. Maydew. 1999. Debt-equity hybrid securities. Journal of Accounting Research 37: 249-274.

Erickson, M. 1998. The effect of taxes on the structure of corporate acquisitions. Journal of Accounting Research 36: 279-298. 
and E. Maydew. 1998. Implicit taxes in high dividend yield stocks. The Accounting Review 73: 435-458.

and S. Wang. 1999. The effect of transaction structure on price: Evidence from subsidiary sales. Working paper, University of Chicago, Chicago, IL.

Gentry, W., D. Kemsley, and C. Mayer. 2000. Are dividend taxes capitalized into share prices? Evidence from real estate investment trusts. Working paper, Columbia University, New York, NY.

Guenther, D. 1999. Investor reaction to anticipated 1997 capital gains tax rate reduction, Working paper, University of Colorado, Boulder, CO.

. 1994. The relation between tax rates and pretax returns: Direct evidence from the 1981 and 1986 tax rate reductions. Journal of Accounting and Economics 18: 379-393.

and M. Willenborg. 1999. Capital gains tax rates and the cost of capital for small business: Evidence from the IPO market. Journal of Financial Economics 53: 385-408.

Harris, L. and E. Gurel. 1986. Price and volume effects associated with changes in the S\&P 500 list: New evidence for the existence of price pressures. Journal of Finance 41: 815-829.

Harris, T., R. Hubbard and D. Kemsley. 2000. The share price effects of dividend taxes and tax imputation credits. Journal of Public Economics. forthcoming.

and D. Kemsley. 1999. Dividend taxation in firm valuation: New evidence. Journal of Accounting Research 37: 275-291.

Hayn, C. 1995. The information content of losses. Journal of Accounting and Economics 20: 125-153.

1989. Tax attributes as determinants of shareholder gains in corporate acquisitions. Journal of Financial Economics. 121-153.

Henning, S. and W. Shaw. 2000. The effect of the tax deductibility of goodwill on purchase price allocations. Journal of the American Taxation Association. forthcoming.

, W. Shaw, and T. Stock. 2000. The effect of taxes on acquisition prices and transaction structure. Journal of the American Taxation Association, Supplement. forthcoming.

Jegadeesh, N. and S. Titman. 1993. Returns to buying winners and selling losers: Implication of stock market efficiency. Journal of Finance 44: 135-148.

Karpoff, J. 1987. The relation between price changes and trading volume: A survey. Journal of Financial and Quantitative Analysis 22: 109-126. 
Ke, B., Petroni, K., and D. Shackelford. 2000. The impact of state taxes on self-insurance. Journal of Accounting and Economics 29:3, forthcoming.

Landsman, W. and D. Shackelford. 1995. The lock-in effect of capital gains taxes: Evidence from the RJR Nabisco leveraged buyout. National Tax Journal 48: 245-59.

Lang, M. and D. Shackelford. 2000. Capitalization of capital gains taxes: Evidence from stock price reactions to the 1997 rate reductions. Journal of Public Economics 76: 69-85.

Lipe, R., L. Bryant, and S. Widener. 1998. Do nonlinearity , firm-specific coefficients, and losses represent distinct factors in the relation between stock returns and accounting earnings? Journal of Accounting and Economics 25:2, 195-214.

McKeown, J. and J. Raedy, 2000, Problems inherent in the use of cross-sectional earnings response coefficients. Working paper, University of North Carolina, Chapel Hill, NC.

Maydew, E., K. Schipper, and L. Vincent. 1999. The impact of taxes on the choice of divestiture method. Journal of Accounting and Economics 28: 117-150.

Ohlson, J. 1995. Earnings, book values and dividends in security valuation. Contemporary Accounting Research. 661-687.

Palepu, K., V. Bernard, and P. Healy. 1996. Business Analyst and Valuation. Cincinnati, OH., Southwestern Publishing.

Poterba, J. and S. Weisbrenner. 1998. Capital gains tax rules, tax loss trading, and turn-of-theyear returns. Working Paper, National Bureau of Economic Research, Cambridge, MA.

Raedy, J. 2000. A reconciliation of stock market anomalies. Working paper, University of North Carolina, Chapel Hill, NC.

Reese, W. 1998. Capital gains taxation and stock market activity: Evidence from IPOs. Journal of Finance 53: 1799-1820.

Shackelford, D. 1991. The market for tax benefits: Evidence from leveraged ESOPs. Journal of Accounting and Economics 14: 117-145.

2000. Stock market reaction to capital gains tax changes: Empirical evidence from the 1997 and 1998 Tax Acts, in Tax Policy and the Economy. Vol. 14. ed. J. Poterba, MIT Press. Cambridge, MA. forthcoming.

and R. Verrecchia. 1999. Intertemporal tax discontinuities, Working Paper \#7451, National Bureau of Economic Research, Cambridge, MA.

Shleifer, A. 1986. Do demand curves for stocks slope down? Journal of Finance 61: 579-590. 
Sinai, T. and J. Gyourko. 1999. The asset price incidence of capital gains taxes: Evidence from the Taxpayer Relief Act of 1997 and publicly-traded real estate firms. Working paper, University of Pennsylvania, Philadelphia, PA.

Stickney, C., Weil, R. and M. Wolfson. 1983. Income taxes and tax transfer leases: General Electric's accounting for a Molotov cocktail. The Accounting Review 58: 439-459. 
Table 1

Change in Marginal Tax Rate for an Individual Investor in Highest Statutory Tax Rate when Stock Qualifies for Long-term Treatment (adapted from Shackelford, 2000)

I

II

III

IV

V

\begin{tabular}{|c|c|c|c|c|c|c|c|}
\hline Date of Sale & $\begin{array}{l}\text { Holding } \\
\text { Period }\end{array}$ & $\begin{array}{c}\text { Statutory tax } \\
\text { rate } \\
\text { Short-term } \\
\text { Gain (STG) or } \\
\text { Loss (STL) } \\
\text { (A) }\end{array}$ & $\begin{array}{l}\text { Statutory tax } \\
\text { rate } \\
\text { Long-term } \\
\text { Gain (LTG) } \\
\\
\text { (B) }\end{array}$ & $\begin{array}{l}\text { Effective tax } \\
\text { rate } \\
\text { Long-term } \\
\text { Loss (LTL) } \\
\\
\text { (C) }\end{array}$ & $\begin{array}{c}\text { Change in } \\
\text { marginal tax rate } \\
\text { when stock goes } \\
\text { long-term if } \\
\text { LTG\$LTL \& } \\
\text { STG\$STL } \\
\text { (A)-(B) }\end{array}$ & $\begin{array}{c}\text { Change in } \\
\text { marginal tax rate } \\
\text { when stock goes } \\
\text { long-term if } \\
\text { LTG\#LTL \& } \\
\text { STG\#STL } \\
\text { (A)-(C) }\end{array}$ & $\begin{array}{c}\text { Change in } \\
\text { marginal tax rate } \\
\text { when stock goes } \\
\text { long-term for all } \\
\text { other combos of } \\
\text { LTG, LTL, } \\
\text { STG, \& STL }\end{array}$ \\
\hline $1 / 1 / 78-10 / 31 / 78$ & 12 & 70 & 35 & 35 & 35 & 35 & 0 \\
\hline $11 / 1 / 78-12 / 31 / 81$ & 12 & 70 & 28 & 35 & 42 & 35 & 0 \\
\hline $6 / 23 / 85-12 / 31 / 86$ & 6 & 50 & 20 & 25 & 30 & 25 & 0 \\
\hline 1987 & 6 & 38.5 & 28 & 38.5 & 10.5 & 0 & 0 \\
\hline $1 / 1 / 88-1 / 1 / 89$ & 6 or $12^{d}$ & 28 & 28 & 28 & 0 & 0 & 0 \\
\hline $1 / 2 / 89-12 / 31 / 90$ & 12 & 28 & 28 & 28 & 0 & 0 & 0 \\
\hline 1991-1992 & 12 & 31 & 28 & 31 & 3 & 0 & 0 \\
\hline $1 / 1 / 93-5 / 6 / 97$ & 12 & 39.6 & 28 & 39.6 & 11.6 & 0 & 0 \\
\hline
\end{tabular}

${ }^{a}$ The effective rate for long-term losses is the statutory rate in all years except before 1987, when only half of net long-term capital losses could be deducted. Thus, in those years, the effective rate is half of the statutory rate.

${ }^{\mathrm{b}}$ The maximum annual capital loss deduction for individuals is $\$ 3000$ in all years. Additional capital losses are carried forward indefinitely. Thus, if total capital losses less total capital gains exceed the annual limit, the marginal rate is reduced, depending on the carryforward utilization period and altered depending on the applicable rate in the year of utilization.

${ }^{\mathrm{c}}$ The holding period shifted from 12 to 6 months, effective for assets purchased after June 22, 1984. Thus, the holding period for property sold during this time period varied depending on the acquisition date.

${ }^{\mathrm{d}}$ The holding period shifted from 6 to 12 months, effective for assets purchased after December 31, 1987. Thus, the holding period for property sold during this time period varied depending on the acquisition date.

${ }^{\mathrm{e}}$ The long-term tax rate on property held mo re than 12 months, but less than 18 months, was 28 percent. 
TABLE 2

Quarterly Earnings Announcements

$\mathrm{n}=71,371 ; 1983-1997$

Panel A: Descriptive Statistics

\begin{tabular}{|l|c|c|c|c|c|c|c|}
\hline & Mean & std dev & $1 \%$ & $25 \%$ & median & $75 \%$ & $99 \%$ \\
\hline$C A R$ & 0.003 & 0.060 & -0.168 & -0.024 & 0.001 & 0.029 & 0.181 \\
\hline$A V$ & 0.004 & 0.011 & -0.003 & 0.000 & 0.001 & 0.004 & 0.045 \\
\hline$U E$ & 0.001 & 0.009 & -0.028 & -0.002 & 0.000 & 0.002 & 0.045 \\
\hline$\triangle P A S T$ & 0.18 & 0.52 & -0.59 & -0.09 & 0.10 & 0.33 & 2.07 \\
\hline$D R A T E$ & 0.11 & 0.10 & 0 & 0.03 & 0.12 & 0.12 \\
\hline$U E * D R A T E$ & 0.00007 & 0.00145 & -0.00377 & -0.00008 & 0 & 0.00015 & 0.00523 \\
\hline$\triangle P A S T * D R A T E$ & 0.017 & 0.061 & -0.097 & -0.003 & 0.001 & 0.029 & 0.237 \\
\hline
\end{tabular}

Panel B: Pearson (Spearman) Correlation Coefficients above (below) diagonal

\begin{tabular}{|c|c|c|c|c|c|c|c|}
\hline & CAR & $A V$ & $U E$ & $\triangle P A S T$ & DRATE & $U E * D R A T E$ & $\triangle P A S T * D R A T E$ \\
\hline$C A R$ & & -0.02 & 0.17 & 0.12 & -0.02 & 0.09 & 0.10 \\
\hline$A V$ & 0.09 & & 0.02 & 0.15 & -0.01 & 0.01 & 0.12 \\
\hline$U E$ & 0.24 & 0.07 & & 0.09 & 0.02 & 0.70 & 0.07 \\
\hline$\triangle P A S T$ & 0.12 & 0.12 & 0.19 & & -0.04 & 0.04 & 0.79 \\
\hline$D R A T E$ & -0.01 & 0.03 & 0.01 & 0.02 & & 0.05 & 0.14 \\
\hline$U E * D R A T E$ & 0.21 & 0.07 & 0.83 & 0.18 & 0.08 & & 0.07 \\
\hline$\triangle P A S T^{*} D R A T E$ & 0.10 & 0.09 & 0.16 & 0.84 & 0.19 & 0.21 & \\
\hline
\end{tabular}

$C A R_{i t}$ is firm i's three-day, cumulative, buy-and-hold abnormal return, beginning on day t-1, where tis the day earnings are announced; $A V_{i t}$ is firm i's average volume over days $\mathrm{t}-1, \mathrm{t}$, and $\mathrm{t}+1$ less the median volume for the 100 days preceding day $\mathrm{t}-1 ; U E_{i t}$ is the announced quarterly earnings for firm $\mathrm{i}$ on day $\mathrm{t}$ less the median IBES forecast within the 60 days before the earnings announcement, scaled by the share price at the end of the quarter for which earnings are released; $\triangle P A S T_{i t}$ is the difference between firm i's stock price at day $\mathrm{t}-1$, adjusted for stock splits and stock dividends, and its stock price at day $\mathrm{t}-\mathrm{n}$ when $\mathrm{n}$ is the number of days in the holding period on day $\mathrm{t}$, divided by its stock price at day $\mathrm{t}-\mathrm{n} ; D R A T E_{t}$ is the maximum statutory short-term capital gains tax rate less the maximum statutory long-term capital gains tax rate on day $\mathrm{t}$. 
TABLE 3

Price and volume responses to public disclosures

Ordinary least squares regression coefficient estimates $(t$-statistics)

\section{Abnormal Returns \\ Dependent Variable}

A $\quad$ B

$\mathrm{B}$

\begin{tabular}{|c|c|c|c|c|c|c|c|}
\hline $\begin{array}{l}\text { Explanatory } \\
\text { Variables }\end{array}$ & prediction & $\begin{array}{c}\text { Earnings } \\
\text { Announcement }\end{array}$ & $\begin{array}{c}\text { S\&P } 500 \\
\text { Addition }\end{array}$ & prediction & $\begin{array}{c}\text { Earnings } \\
\text { Announcement }\end{array}$ & prediction & $\begin{array}{c}\text { S\&P 500 } \\
\text { Addition }\end{array}$ \\
\hline Intercept & & $\begin{array}{c}-0.002 \\
(-1.0)\end{array}$ & $\begin{array}{c}0.034 \\
(2.6)\end{array}$ & & $\begin{array}{l}0.005 \\
(15.4)\end{array}$ & & $\begin{array}{c}0.003 \\
(1.4)\end{array}$ \\
\hline$U E$ & & $\begin{array}{l}2.518 \\
(9.8) \\
\end{array}$ & & & $\begin{array}{l}0.097 \\
(2.1) \\
\end{array}$ & & \\
\hline JOIN & & & $\begin{array}{c}0.010 \\
(1.7) \\
\end{array}$ & & & & $\begin{array}{l}0.002 \\
(2.4) \\
\end{array}$ \\
\hline$\triangle P A S T$ & & $\begin{array}{l}0.009 \\
(12.0)\end{array}$ & $\begin{array}{l}-0.020 \\
(-1.9)\end{array}$ & & $\begin{array}{l}0.003 \\
(25.4)\end{array}$ & & $\begin{array}{l}0.002 \\
(1.2)\end{array}$ \\
\hline DRATE & & $\begin{array}{l}0.001 \\
(0.1)\end{array}$ & $\begin{array}{l}-0.024 \\
(-0.6)\end{array}$ & & $\begin{array}{l}-0.001 \\
(-0.4)\end{array}$ & & $\begin{array}{l}-0.005 \\
(-0.8)\end{array}$ \\
\hline$U E * D R A T E$ & $(+)$ & $\begin{array}{l}1.475 \\
(1.7)\end{array}$ & & $(-)$ & $\begin{array}{l}0.195 \\
(1.3) \\
\end{array}$ & & \\
\hline$J O I N * D R A T E$ & $(+)$ & & $\begin{array}{l}-0.022 \\
(-0.8)\end{array}$ & & & (?) & $\begin{array}{l}0.005 \\
(1.2)\end{array}$ \\
\hline$\triangle P A S T^{*} D R A T E$ & $(+)$ & $\begin{array}{l}0.022 \\
(3.4)\end{array}$ & $\begin{array}{l}0.100 \\
(2.5)\end{array}$ & $(-)$ & $\begin{array}{l}-0.005 \\
(-4.3)\end{array}$ & $(?)$ & $\begin{array}{l}-0.002 \\
(-0.3)\end{array}$ \\
\hline $\operatorname{adj} . \mathrm{R}^{2}$ & & 0.05 & 0.06 & & 0.03 & & 0.04 \\
\hline $\mathrm{n}$ & & 71,371 & 399 & & 71,371 & & 399 \\
\hline
\end{tabular}

For earnings announcement tests, the dependent variable is $C A R_{i t}$, firm i's three-day, cumulative, buy-and-hold abnormal return, beginning on day $\mathrm{t}-1$, where $\mathrm{t}$ is the day earnings are announced; for $\mathrm{S} \& \mathrm{P} 500$ addition tests, the dependent variable is $C A R_{i t}$, firm i's five-day, cumulative, buy-and-hold abnormal return, beginning on day $\mathrm{t}$, where $\mathrm{t}$ is the first trading day

following the announcement; for abnormal volume tests, the dependent variable is $A V_{i t}$, firm i's average volume over days t-1, $\mathrm{t}$, and $\mathrm{t}+1$ less the median volume for the 100 days preceding day $\mathrm{t}-1 ; \operatorname{JOIN}_{t}$ is the percentage of equity mutual fund assets held in index funds during the year that includes day t. See Table 2 for other variable definitions. 
TABLE 4

Standard \& Poor's 500 Additions

$\mathrm{n}=399 ; 1978-1998$

Panel A: Descriptive Statistics

\begin{tabular}{|l|c|c|c|c|c|c|c|}
\hline & mean & std dev & $1 \%$ & $25 \%$ & median & $75 \%$ & $99 \%$ \\
\hline$C A R$ & 0.044 & 0.054 & -0.065 & 0.013 & 0.042 & 0.073 & 0.195 \\
\hline$J O I N$ & 2.2 & 2.2 & 0.2 & 0.4 & 1.3 & 4.2 & 6.5 \\
\hline$\triangle P A S T$ & 0.30 & 0.47 & -0.37 & 0.02 & 0.19 & 0.48 & 2.17 \\
\hline$D R A T E$ & 0.20 & 0.14 & 0 & 0.12 & 0.20 & 0.30 & 0.42 \\
\hline JOIN * DRATE & 0.32 & 0.41 & 0 & 0.08 & 0.12 & 0.50 & 1.30 \\
\hline$\triangle P A S T^{*}$ DRATE & 0.06 & 0.12 & -0.15 & 0 & 0.02 & 0.09 & 0.61 \\
\hline
\end{tabular}

Panel B: Pearson (Spearman) Correlation Coefficients above (below) diagonal

\begin{tabular}{|c|c|c|c|c|c|c|}
\hline & $C A R$ & JOIN & $\triangle P A S T$ & DRATE & $J O I N * D R A T E$ & $\triangle P A S T * D R A T E$ \\
\hline$C A R$ & & 0.25 & 0.06 & -0.16 & 0.19 & 0.05 \\
\hline JOIN & 0.24 & & 0.20 & -0.45 & 0.89 & -0.01 \\
\hline$\triangle P A S T$ & 0.03 & 0.16 & & 0.03 & 0.21 & 0.79 \\
\hline$D R A T E$ & -0.21 & -0.67 & 0.01 & & -0.06 & 0.34 \\
\hline$J O I N * D R A T E$ & 0.10 & 0.60 & 0.16 & 0.07 & & 0.12 \\
\hline$\triangle P A S T * D R A T E$ & 0.00 & -0.02 & 0.85 & 0.32 & 0.25 & \\
\hline
\end{tabular}

See Tables 2 and 3 for variable definitions. 
TABLE 5

Taxable individual ownership

Ordinary least squares regression coefficient estimates (t-statistics)

\begin{tabular}{|c|c|c|c|c|c|}
\hline & & \multicolumn{2}{|c|}{ Abnormal Returns } & \multicolumn{2}{|c|}{ Abnormal Volu } \\
\hline & & $\begin{array}{c}\text { Earnings } \\
\text { Releases }\end{array}$ & $\begin{array}{l}\text { S\&P } 500 \\
\text { Additions }\end{array}$ & & $\begin{array}{l}\text { Earnings } \\
\text { Releases }\end{array}$ \\
\hline Explanatory variables & pred & Coef & Coef & Pred & Coef \\
\hline Intercept & & $\begin{array}{c}-0.002 \\
(-1.4)\end{array}$ & $\begin{array}{c}0.031 \\
(2.4)\end{array}$ & & $\begin{array}{l}0.005 \\
(15.8)\end{array}$ \\
\hline$U E$ & & $\begin{array}{l}3.437 \\
(10.0)\end{array}$ & & & $\begin{array}{c}0.121 \\
(2.0)\end{array}$ \\
\hline JOIN & & & $\begin{array}{c}0.010 \\
(1.8)\end{array}$ & & \\
\hline$\triangle P A S T$ & & $\begin{array}{c}0.008 \\
(8.9)\end{array}$ & $\begin{array}{c}-0.018 \\
(-1.9)\end{array}$ & & $\begin{array}{l}0.003 \\
(21.2)\end{array}$ \\
\hline$D R A T E$ & & $\begin{array}{c}0.001 \\
(0.1)\end{array}$ & $\begin{array}{c}-0.030 \\
(-0.7)\end{array}$ & & $\begin{array}{c}-0.001 \\
(-0.6)\end{array}$ \\
\hline$U E * D R A T E$ & & $\begin{array}{c}0.385 \\
(0.4)\end{array}$ & & & $\begin{array}{c}-0.107 \\
(-0.6)\end{array}$ \\
\hline$J O I N * D R A T E$ & & & $\begin{array}{c}-0.018 \\
(-0.6)\end{array}$ & & \\
\hline$\triangle P A S T * D R A T E$ & & $\begin{array}{c}0.032 \\
(4.0) \\
\end{array}$ & $\begin{array}{c}0.118 \\
(2.8) \\
\end{array}$ & & $\begin{array}{c}-0.003 \\
(-2.4) \\
\end{array}$ \\
\hline IND & & $\begin{array}{c}0.001 \\
(1.2)\end{array}$ & $\begin{array}{c}0.062 \\
(1.5)\end{array}$ & & $\begin{array}{c}-0.001 \\
(-6.6)\end{array}$ \\
\hline$I N D * U E$ & & $\begin{array}{l}-2.127 \\
(-4.1)\end{array}$ & & & $\begin{array}{c}-0.063 \\
(-0.7)\end{array}$ \\
\hline$I N D * J O I N$ & & & $\begin{array}{c}-0.039 \\
(2.1)\end{array}$ & & \\
\hline$I N D^{*} \triangle P A S T$ & & $\begin{array}{c}0.002 \\
(1.3)\end{array}$ & $\begin{array}{c}-0.033 \\
(-0.6)\end{array}$ & & $\begin{array}{c}-0.003 \\
(1.2)\end{array}$ \\
\hline$I N D * D R A T E$ & & $\begin{array}{c}-0.003 \\
(-0.6)\end{array}$ & $\begin{array}{c}-0.185 \\
(-1.3)\end{array}$ & & $\begin{array}{c}0.001 \\
(1.2)\end{array}$ \\
\hline$I N D^{*} U E * D R A T E$ & $(+)$ & $\begin{array}{c}2.942 \\
(1.7)\end{array}$ & & $(-)$ & $\begin{array}{c}0.700 \\
(2.3)\end{array}$ \\
\hline$I N D * J O I N * D R A T E$ & $(+)$ & & $\begin{array}{c}0.185 \\
(2.0)\end{array}$ & & \\
\hline$I N D^{*} \triangle P A S T * D R A T E$ & $(+)$ & $\begin{array}{c}-0.028 \\
(-2.2)\end{array}$ & $\begin{array}{c}0.098 \\
(0.5)\end{array}$ & $(-)$ & $\begin{array}{c}-0.005 \\
(-2.0)\end{array}$ \\
\hline $\operatorname{adj} . R^{2}$ & & 0.05 & 0.10 & & 0.04 \\
\hline $\mathrm{n}$ & & 71,371 & 344 & & 71,371 \\
\hline
\end{tabular}

$I N D_{i t}$ is one if 75 percent of firm i's shares are owned by non-institutions, zero otherwise. See Tables 2 and 3 for other variable definitions. 
TABLE 6

Price responses following the disclosure period

Ordinary least squares regression coefficient estimates $(t$-statistics)

$\begin{array}{llll}\text { A } & \text { B } & \text { C } & \text { D }\end{array}$

Earnings Announcement

\begin{tabular}{|c|c|c|c|c|c|}
\hline $\begin{array}{l}\text { Explanatory } \\
\text { Variables }\end{array}$ & prediction & 3-day & 10-day & $5-d a y$ & 10-day \\
\hline Intercept & & $\begin{array}{l}-0.002 \\
(-1.6)\end{array}$ & $\begin{array}{l}0.006 \\
(2.9)\end{array}$ & $\begin{array}{c}0.005 \\
(0.5)\end{array}$ & $\begin{array}{c}0.003 \\
(0.2)\end{array}$ \\
\hline$U E$ & & $\begin{array}{c}-0.089 \\
(-0.5)\end{array}$ & $\begin{array}{l}0.557 \\
(1.8)\end{array}$ & & \\
\hline JOIN & & & & $\begin{array}{c}-0.006 \\
(-1.4)\end{array}$ & $\begin{array}{c}-0.001 \\
(-0.1)\end{array}$ \\
\hline$\triangle P A S T$ & & $\begin{array}{l}-0.004 \\
(-7.5)\end{array}$ & $\begin{array}{l}-0.003 \\
(-2.8)\end{array}$ & $\begin{array}{c}0.010 \\
(1.2)\end{array}$ & $\begin{array}{l}-0.008 \\
(-0.7)\end{array}$ \\
\hline$D R A T E$ & & $\begin{array}{l}-0.006 \\
(-0.9)\end{array}$ & $\begin{array}{l}-0.020 \\
(-1.9)\end{array}$ & $\begin{array}{l}-0.011 \\
(-0.3)\end{array}$ & $\begin{array}{l}-0.012 \\
(-0.2)\end{array}$ \\
\hline$U E * D R A T E$ & $(-)$ & $\begin{array}{l}-1.558 \\
(-2.6)\end{array}$ & $\begin{array}{l}-0.694 \\
(-0.7)\end{array}$ & & \\
\hline JOIN * DRATE & $(?)$ & & & $\begin{array}{c}0.026 \\
(1.3)\end{array}$ & $\begin{array}{l}-0.015 \\
(-0.5)\end{array}$ \\
\hline$\triangle P A S T * D R A T E$ & $(-)$ & $\begin{array}{l}0.011 \\
(2.3)\end{array}$ & $\begin{array}{l}-0.008 \\
(-1.1)\end{array}$ & $\begin{array}{l}-0.051 \\
(-1.7)\end{array}$ & $\begin{array}{l}-0.008 \\
(-0.2)\end{array}$ \\
\hline adj. $R^{2}$ & & 0.00 & 0.00 & 0.00 & 0.01 \\
\hline$n$ & & 71,308 & 71,308 & 397 & 397 \\
\hline
\end{tabular}

For quarterly earnings announcements $C A R_{i t}$ is firm i's cumulative, buy-and-hold abnormal return, beginning on day $\mathrm{t}+2$, where $\mathrm{t}$ is the day earnings are announced; For $\mathrm{S} \& \mathrm{P} 500$ additions, $C A R_{i t}$ is firm i's cumulative, buy-and-hold abnormal return, beginning on day $t+5$, where $t$ is the first trading day following the announcement. See Tables 2 and 3 for other variable definitions. 